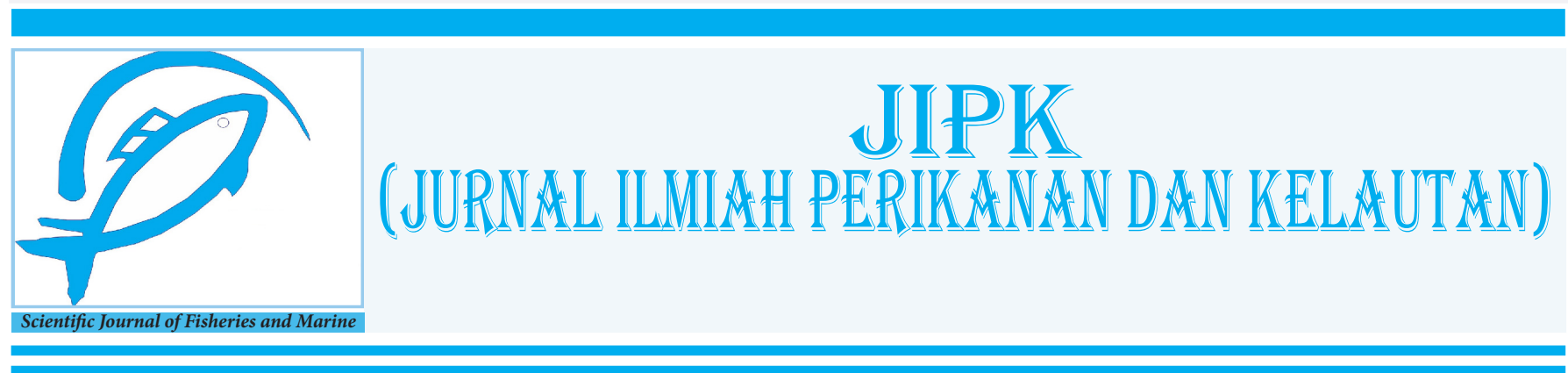

Research Article

\title{
The Effect of Using Bromelain and Papain Enzymes on the Quality of Pure Fish Oil from Milkfish Silage (Chanos chanos)
}

\section{Yosie Prayudha Arisky, Supriyanto* iD, and Mohammad Fakhry}

Program Study of Agroindustrial Technology, Faculty of Agriculture, Universitas Trunojoyo Madura, Bangkalan, East Java, 69162. Indonesia

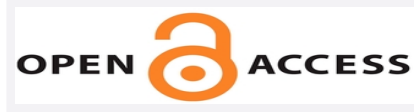

\section{ARTICLE INFO}

Received: March 07, 2021

Accepted: September 16, 2021

Published: September 28, 2021

*) Corresponding author:

E-mail:priyantosby17@gmail.com

Keywords:

Enzymatic Extraction

Fatty Acids Content

Morphology

This is an open access article under the CC BY-NC-SA license (https://creativecommons.org/ licenses/by-nc-sa/4.0/)

\begin{abstract}
Milkfish has a high nutritional content, especially fat content. The processing of milkfish oil into pure oil has not been done much. Proper processing is needed so that the fatty acids contained in fish can be utilized optimally for pharmaceutical and medical needs. Enzyme extraction is known to extract fish oil with better quality than the heating method. The aim of this research was to study the effect of the enzymes bromelain and papain on the quality of pure fish oil from milkfish silage by treating different body parts used. The experiment was carried out with Factorial Complete Randomized Design with three replications involving two factors. The first factor was the type of enzyme using two types of enzymes, namely bromelain and papain with a concentration of $15 \%$, the second factor used was the difference in body parts that was whole fish, flesh, and waste (head, viscera, and bones). The results showed that the type of enzyme had no significant effect on the quality of fish oil, but the different treatments of fish body parts had a significant effect on the quality of the fish oil produced. The best treatment was adapted from fish oil treated using the bromelain enzyme with the flesh. This treatment resulted in yield of $1.25 \%$, density $0.903 \mathrm{~g} / \mathrm{mL}$, FFA content of $0.56 \%$, and peroxide value of $7.64 \mathrm{meq} / \mathrm{kg}$.
\end{abstract}

Cite this as: Arisky, Y. P., Supriyanto, \& Fakhry, M. (2021). The Effect of Using Bromelain and Papain Enzymes on the Quality of Pure Fish Oil from Milkfish Silage (Chanos chanos). Jurnal Ilmiah Perikanan dan Kelautan, 13(2):233-242. http://doi.org/10.20473/jipk.v13i2.25827 


\section{Introduction}

Milkfish (Chanos chanos) is a fish with high economic value. Indonesia is the largest producer of milkfish after the Philippines. According to the FAO Regional Officer for Asia and The Pacific, the consumption of milkfish in Indonesia is 187,200 tons (Needham and Funge-Smith, 2015). Milkfish are generally processed as whole milkfish, thorn less, and presto milkfish. Then from an industrial scale, milkfish are mostly processed into canned fish and concentrate for animal feed. Utilization of milkfish into fish oil is still minimal and needs to be increased considering the benefits of milkfish's high nutritional content. The nutritional content of milkfish includes $20.37 \%$ protein, $3.84 \%$ fat, and $4.02 \%$ ash. The essential amino acids (0.1 g of sample) are glutamic acid (16.2 g), aspartic acid (12 g), leucine ( $8 \mathrm{~g})$, lysine ( $7.3 \mathrm{~g})$, phenylalanine $(6.7 \mathrm{~g})$, and histidine $(6.1 \mathrm{~g})$. The content of saturated fatty acids (SFA) was $40.17 \%$, Mono Unsaturated Fatty Acid (MUFA) was $34.47 \%$, and Poly Unsaturated Fatty Acid (PUFA) was 16.27\% (Murthy et al., 2016). The $\omega 3$ content of milkfish $(0.1 \mathrm{~g}$ sample) is divided into $0.36 \mathrm{~g}$ EPA and $1.17 \mathrm{~g}$ DHA. This shows that milkfish contains quite a lot of $\omega 3 \mathrm{~s}$ so that it can be used as an alternative source of useful fatty acids (Sugata et al., 2019).

Fish oil processing is one way to optimize the potential of milkfish. Fish oil is a component of fat in fish body tissue that has been extracted in the form of oil. Several studies on fish oil production with raw materials for fishery products include mackerel byproduct (Ramakrishnan et al., 2013), goldfish (Pandiangan et al., 2019), sardines (Sardinella longiceps) (Al-Abri et al., 2014), ribbon fish (Lepturacanthus savala) (Akhade et al., 2016), fish waste (Lúcia et al., 2015), fish oil microencapsulation (Liu et al., 2016), and mackerel fish oil waste (Feryana et al., 2014). The problem that is obtained from these various studies is fish oil quality is less than optimal so that it requires an effective extraction and purification method. The extraction method is the key step that most influences the quality of the pure fish oil produced.

The method commonly used for fish oil extraction is the rendering method or heating by pressing. The lack of this method is the use of high temperatures which results in low quality of fatty acids and resulting in waste of energy, thus increasing costs. The extraction method that can be used to overcome these deficiencies includes the enzymatic extraction method. According to research by Taati et al. (2018), the fish oil extraction method using protease enzyme is better than the pressing method (wet process) in terms of yield and fatty acid content in fish oil.

Bromelain and papain enzymes are protease enzymes that can be used to extract fish oil. Bromelain is a protease enzyme found in pineapple plants, while papain is a natural protease enzyme found in papaya plants. Both types of enzymes fall into the category of protease enzymes, could breaks down proteins into simpler amino acids. Enzymes have high functionality because they can work back and forth to be very good when used for extraction.

Several studies regarding enzymatic extraction in fish oil processing include research by Mbatia et al. (2010) with raw materials tillapia and salmon fish using $0.5 \%$ bromelain enzyme without the addition of water and $\mathrm{pH}$ at $55^{\circ} \mathrm{C}$, salmon byproduct a mixture of head, body, and viscera using the protease enzyme $2.5 \%$ at $50^{\circ} \mathrm{C}$ (Routray et al., 2018), alkylase enzymes (Ramakrishnan et al., 2013), and four types of protease enzymes (Protease-P-Amano6, Alcalase ${ }^{\circledR}$, Protex $7 \mathrm{~L} \AA$, and Neutrase ${ }^{\circledR}$ ) (Hathwar et al., 2011). Some of these studies only focus on the effect of enzymes with whole fish raw materials so that the effect of differences in fish body parts on fish oil quality is unknown. This study examines the effect of bromelain and papain enzymes on the quality of pure fish oil by treating different body parts.

\section{Materials and Methods}

\subsection{Materials}

The materials used in this study included milkfish (Chanos chanos), pineapple fruit extract and papaya peel extract (as crude enzymes) obtained from the Kamal market Bangkalan Regency, citric acid monohydrate (5949-29-1, Emsure $\left.{ }^{\circledR}, \mathrm{DEU}\right), \mathrm{NaOH}$ (109139, Emsure $\left.{ }^{\circledR}, \mathrm{DEU}\right), \mathrm{KOH}$ (111787, Titripur $\AA$, DEU), Potassium Iodide (105044, Suprapur ${ }^{\circledR}$, DEU), distilled water, bentonite, Phenolphthalein (107233, Merck, DEU), 1\% starch indicator, glacial acetic acid (100063, Emsure ${ }^{\circledR}$, DEU), chloroform (102445, Emsure $\left.{ }^{\circledR}, \mathrm{DEU}\right), \mathrm{Na}_{2} \mathrm{~S}_{2} \mathrm{O}_{3}$ (160312, Titripur $\left.{ }^{\circledR}, \mathrm{DEU}\right)$, hexane (100795, SupraSolv $\left.{ }^{\circledR}, \mathrm{DEU}\right)$, and $96 \%$ ethanol (159010, Emsure $\AA$, DEU). The equipment used were UV-Vis spectrophotometer (Genesys 10s UV-Vis, Thermo Scientific ${ }^{\mathrm{TM}}$, USA), blender (8011ES, Waring ${ }^{\circledR}$, USA), erlenmeyer (4980-250N, Iwaki ${ }^{\circledR}$, INA), beaker glass $\left(1000\right.$, pyrex ${ }^{\circledR}$, DEU), measuring pipette $(7000$ 20-IW, Iwaki ${ }^{\circledR}$, INA), hot plate (SP88857104, Thermo Scientific $^{\mathrm{TM}}$ Cimarec+TM, USA), spatula, measuring cylinder (3022-25-N, Iwaki ${ }^{\circledR}$, INA), volumetric flask (5640-1000-IW, Iwaki®, INA), analytical balance 
JIPK. Volume 13 No 2. November 2021 / The Effect of Using Bromelain and Papain Enzymes on the Quality of ...

(Cp214, Ohaus ${ }^{\circledR}$, CHN), centrifuge (LC-04S, Zenith Lab, CHN), cuvette, magnetic stirring bar, burette (BURET25S, Iwaki ${ }^{\circledR}$, INA), aluminum foil, and gas chromatography devices (GC-MS QP-2010).

\subsection{Methods}

A field experiment was conducted at the quality analysis laboratory, Universitas Trunojoyo Madura, from September to December 2020 to study the effect of the enzymes bromelain and papain on the quality of pure fish oil milkfish silage by treating different body parts of the milkfish.

\subsubsection{Experimental design}

This study used an experimental method, which is the method used to find the effect of one treatment on another treatment under controlled conditions. The data collection technique was carried out by direct observation, namely by using the physical test of pure milkfish oil. The experiment used a factorial Completely Randomized Design (CRD) with three replications involving two factors; the first factor was the type of enzyme using two types of enzymes, namely bromelain and papain with a concentration of $15 \%$, the second factor used was the difference in body parts that was whole fish, flesh, and waste (head, viscera, and bones).

\subsubsection{Sample Treatment}

\subsubsection{Crude Fish Oil Processing (Gbogouri et al., 2006 modified)}

Crude fish oil processing begins with cleaning and separating the milkfish based on treatment (whole, flesh, and waste). Each piece is weighed $500 \mathrm{~g}$ and then reduced in size using a grinder. The fish silage was then added with crude protease enzymes (bromelain and papain) to each treatment as much as $15 \%(\mathrm{v} / \mathrm{v})$ then heated at $56^{\circ} \mathrm{C}$ for 120 minutes. The hydrolyzed fish oil was centrifuged at a speed of $4000 \mathrm{rpm}$ for 20 minutes, and then the residue was re-centrifuged at a speed of $2600 \mathrm{rpm}$ for 10 minutes to ensure the residue was clean from oil. The crude fish oil is separated using a dropper.

\subsubsection{Purification}

Crude fish oil was purified using three stages to get pure fish oil. Degumming: The crude fish oil sample was weighed as needed in a $50 \mathrm{~mL}$ beaker glass, then 3\% $(\mathrm{w} / \mathrm{w})$ concentration of $3 \%$ citric acid solution was added and stirred on a hot plate at $70^{\circ} \mathrm{C}$ for 1 minute. Then the oil was rested and centrifuged at $2600 \mathrm{rpm}$ for 10 minutes to separate the degumming fish oil (Pravinkumar et al., 2015). Neutralization: $\mathrm{NaOH}$ solution with a concentration of $9.5 \%$ as much as $18^{\circ} \mathrm{Be}(12.68 \%$ $(\mathrm{w} / \mathrm{w}))$ was added to the degumming oil then stirred using a magnetic stirrer and heated at $65^{\circ} \mathrm{C}$ for 20 minutes. The samples were rested at room temperature for 3 hours. After resting, the samples were centrifuged at a speed of $2600 \mathrm{rpm}$ for 10 minutes. The centrifuged oil was separated from the soap sediment by adding 50 $\mathrm{mL}$ of distilled water to wash the remaining soap, then centrifuged again with 3 repetitions to ensure that the oil is clean from the soap (Dieffenbacher and Pocklington, 1992). Bleaching: The neutralized fish oil was added with $1 \mathrm{~g}$ of bentonite at $100^{\circ} \mathrm{C}$ for 20 minutes and then centrifuged at $2600 \mathrm{rpm}$ for 10 minutes (Makhoukhi et al., 2009).

\subsubsection{Physical properties of the fish oils}

\subsubsection{Yield (Helrich, 1990)}

The yield is the ratio between the final weight of the product and the ingredients' initial weight. The yield was calculated based on (Helrich, 1990) as follows:

Yield $(\%)=\frac{\text { Final Weight }(\mathrm{g})}{\text { Initial Weight }(\mathrm{g})} \times 100$

\subsubsection{Density (Apituley et al., 2020)}

Density is the weight of the object divided by its volume. The formula used to find the density value is as follows:

Density $(\mathrm{g} / \mathrm{mL})=\frac{\text { Weight }(\mathrm{g})}{\text { Volume }(\mathrm{mL})}$

\subsubsection{Clarity (Helrich, 1990) modified by (Suseno et al., 2011)}

The usable wavelengths based on the modified method (Helrich, 1990; Suseno et al., 2011) are 450 to $700 \mathrm{~nm}$. The cuvette was cleaned and filled with aquadest until it showed an absorbance of $0 \mathrm{~A}$. The cuvette containing the standard was replaced with a cuvette containing the sample, and the clarity was measured based on the percentage of transmission (\% T). The sample was measured by mixing $0.5 \mathrm{~mL}$ of oil with $9 \mathrm{~mL}$ hexane at a wavelength of $450 \mathrm{~nm}$.

\subsubsection{Colour (Helrich, 1990)}

A sample of $5-10 \mathrm{~mL}$ was prepared in a $50 \mathrm{~mL}$ beaker. Then the sample is taken using a pipette as much as $0.5 \mathrm{~mL}$ and placed on the test plate evenly. The pipette sample must be clean of residue or dirt, so it is advisable to take the top part of the oil in the beaker. The samples were analyzed using the Hunterlab colorFlex EZ color reader with a height of $\pm 2 \mathrm{~cm}$ using the Hunter methods $L^{*}, a^{*}$, and $b^{*}$. $L^{*}$ values measure lightness $(0=$ black 
and $100=$ white); $+\mathrm{a}^{*}$ values represent redness, and $-\mathrm{a} *$ values represent greenness; $+b^{*}$ values represent yellow ; and $-\mathrm{b}^{*}$ values represent blue. Measurement was carried out three times, and the results were averaged.

\subsubsection{Chemical Properties}

\subsubsection{Percent Free Fatty Acids (Helrich, 1990)}

A sample of $0.5 \mathrm{~g}$ was put into a $250 \mathrm{~mL}$ Erlenmeyer then added $5 \mathrm{~mL}$ of $96 \%$ ethanol. The sample was heated for 10 minutes at $70-80^{\circ} \mathrm{C}$ and cooled at room temperature, and then two drops of phenolphthalein (PP) indicator were added. The sample was stirred for 1 minute and irritated using $0.1 \mathrm{~N} \mathrm{KOH}$ solution until a pink color was formed that lasted for 30 seconds. Then the percentage of free fatty acid content FFA $(\%)=\frac{A \times N \times M}{G \times 1000} \times 100 \%$

\section{Description:}

$\mathrm{A}=$ Number of $\mathrm{KOH}$ titrations $(\mathrm{mL})$

$\mathrm{N}=$ Normality of $\mathrm{KOH}$

$\mathrm{M}=$ Molecular Weight of dominant fatty acid (Palmitic Acid)

$\mathrm{G}=$ The sample (gram)

\subsubsection{Peroxide Value (Helrich, 1990)}

The oil was weighed as much $0.5 \mathrm{~g}$, put in a $250 \mathrm{~mL}$ Erlenmeyer and $30 \mathrm{~mL}$ of chloroform (3:2 in volume), then glacial acetic acid solution was added. The mixture was shaken for 1 minute, and $0.5 \mathrm{~mL}$ of saturated KI solution was added. The solution was shaken for 1 minute then added $30 \mathrm{~mL}$ of distilled water and 0.5 $\mathrm{mL}$ of $1 \%$ starch indicator. The color of the mixture that appears before the titration is blackish blue, and then the solution was titrated with $0.01 \mathrm{~N} \mathrm{Na}_{2} \mathrm{~S}_{2} \mathrm{O}_{3}$ solution until the blue color disappears. The calculation of the peroxide value is done with the following equation:

Peroxide Value $(\mathrm{meq} / \mathrm{kg})=\frac{\mathrm{S} \times \mathrm{N} \times 1000}{\text { Sample Weight }(\mathrm{g})}$

Description:

$\mathrm{S}=$ Volume of titration $\mathrm{Na}_{2} \mathrm{~S}_{2} \mathrm{O}_{3}(\mathrm{~mL})$

$\mathrm{N}=$ Normality for $\mathrm{Na}_{2} \mathrm{~S}_{2} \mathrm{O}_{3}$

\subsubsection{Fatty acid profile}

The analysis of the fatty acid profile was carried out on fish oil with the best characteristics which is the treatment of flesh with the enzyme bromelain. The analysis begins with the fish oil transesterification process. The sample was prepared as much $25 \mathrm{mg}$ and put into the derivatization tube. $1 \mathrm{~mL}$ of $2 \% \mathrm{NaOH}$ solution (in methanol) was added and shaken for 1 minute. The tube is tightly closed and heated to $90^{\circ} \mathrm{C}$ for 5 minutes then cooled. $1 \mathrm{~mL}$ of BF3 solution in methanol was added and heated again at $90^{\circ} \mathrm{C}$ for 30 minutes and rested. $1 \mathrm{~mL}$ of $\mathrm{n}$-hexane solution was added and shaken for 30 seconds. The upper phase (n-hexane) was taken for analysis using the Agilent 5977B GC/MSD instrument with the Agilent 5973 inert MSD detector.

A total of $1 \mu \mathrm{L}$ of the free liquid phase solution was injected into the J\&W Scientific column, HP-5MS (5\% -phenyl-methylpolysiloxane), as a buffer. The column length used $30 \mathrm{~m}$, with a diameter of $0.25 \mathrm{~mm}$. The injector's temperature was set at $230^{\circ} \mathrm{C}$, and the detector temperature was $280^{\circ} \mathrm{C}$, then Helium gas was used as a carrier gas. The initial column was set to the temperature of $170^{\circ} \mathrm{C}$, held for 1 minute, increased the temperature slowly by $2^{\circ} \mathrm{C} /$ minute until the temperature is $180^{\circ} \mathrm{C}$ then held for 5 minutes, increased the temperature slowly by $5^{\circ} \mathrm{C} /$ minute until the temperature is $275^{\circ} \mathrm{C}$ and then held for 5 minutes. The best sample analysis is done qualitatively in terms of retention time compared to the standard fatty acid standard. While quantitatively it is calculated based on the peak area of one fatty acid divided by the total peak area multiplied by $100 \%$ in order to obtain the composition of fatty acids in the sample.

\subsection{Data Analysis}

The data obtained were then compared with International Fish Oil Standard (IFOS) and Indonesian National Standard (SNI) on pure fish oil. The data obtained were analyzed using the analysis of variance at the $5 \%$ alpha significance level with the help of SPSS software version 16. If there was a significant difference from the results of the analysis, then proceed with the Duncan difference test.

\section{Results and Discussion}

\subsection{The Effect of Treatment on Physical Properties}

Most studies only use whole fish or fish body parts specifically. However, the effect of different body parts on the physical and chemical properties is not yet known. Each part of the fish's body has different characteristics due to its fatty acid content. This will also affect the hydrolysis process and the forming of fatty acid compounds and peroxides; resulting in differentclarity, color, specific gravity, and yield. The whole fish hydrolyzed with the bromelain enzyme yielded $0.92 \%$ of the initial weight of $500 \mathrm{~g}$ of material (Table 1). Whole fish hydrolyzed with papain enzyme 
had a yield of $1.02 \%$, flesh hydrolyzed with bromelain resulted in a yield of $1.25 \%$, flesh hydrolyzed with papain resulted in a yield of $0.81 \%$. The highest yield was waste hydrolyzed with bromelain at $1.28 \%$, and the lowest was waste with papain at $0.72 \%$. The treatment of flesh and garbage with the bromelain enzyme was higher yield than treatment with the papain enzyme papain. On the contrary, the yield of whole fish with the papain enzyme was higher than that of whole fish with the bromelain enzyme. The ability of enzymes is influenced by the fatty acid content in the fish body. acids contained in it, the more branched fatty acids or unsaturated fatty acids, the higher the specific gravity of the oil.

Color test results using the colourreader showed that pure fish oil from flesh treatment has a brightness level of 31.4 and 34.3. Pure fish oil from waste treatment has a brightness level of 33.3 and 30.9. So it can be seen that fish oil with the highest brightness is a whole fish oil with papain enzyme, while the lowest is waste fish oil with papain enzyme. The treatment with the highest $a^{*}$ value was the treatment of waste with bromelain

Table 1. Physical properties of pure fish oil from Milkfish Silage (Chanos chanos) from Kamal market, Bangkalan

\begin{tabular}{|c|c|c|c|c|c|c|}
\hline \multirow{2}{*}{ Parameter } & \multicolumn{6}{|c|}{ Treatment } \\
\hline & P1 & $\mathbf{P 2}$ & P3 & P4 & P5 & P6 \\
\hline Yield (\%) & $0.92 \pm 1.00^{\mathrm{b}}$ & $1.02 \pm 1.00^{\mathrm{c}}$ & $1.25 \pm 0.18^{\mathrm{d}}$ & $0.81 \pm 0.06^{\mathrm{a}}$ & $1.28 \pm 0.18^{\mathrm{d}}$ & $0.72 \pm 0.06^{\mathrm{a}}$ \\
\hline $\begin{array}{l}\text { Density (g/ } \\
\mathrm{mL})\end{array}$ & $0.902 \pm 0.69^{\mathrm{a}}$ & $0.944 \pm 1.00^{\mathrm{d}}$ & $0.903 \pm 0.05^{\mathrm{ab}}$ & $0.920 \pm 0.09^{c}$ & $0.912 \pm 0.05^{\mathrm{bc}}$ & $0.917 \pm 0.09^{\mathrm{bc}}$ \\
\hline Clarity (A) & $0.067 \pm 1.00^{\mathrm{a}}$ & $0.091 \pm 1.00^{\mathrm{b}}$ & $0.241 \pm 1.00^{\mathrm{f}}$ & $0.197 \pm 1.00^{\mathrm{e}}$ & $0.131 \pm 1.00^{c}$ & $0.155 \pm 1.00^{\mathrm{d}}$ \\
\hline $\mathrm{L}^{*}$ & $32.2 \pm 0.09^{\mathrm{a}}$ & $36.2 \pm 0.09^{\mathrm{a}}$ & $31.4 \pm 0.09^{\mathrm{a}}$ & $34.3 \pm 0.09^{\mathrm{a}}$ & $33.3 \pm 0.09^{\mathrm{a}}$ & $30.9 \pm 0.09^{\mathrm{a}}$ \\
\hline$a^{*}$ & $+1.47 \pm 0.54^{\mathrm{a}}$ & $+2.03 \pm 0.54^{\mathrm{a}}$ & $+1.03 \pm 0.54^{\mathrm{a}}$ & $+1.90 \pm 0.54^{\mathrm{a}}$ & $+3.10 \pm 1.00^{\mathrm{b}}$ & $+1.07 \pm 0.54^{\mathrm{a}}$ \\
\hline$b^{*}$ & $+21.2 \pm 0.14^{\mathrm{a}}$ & $+22.9 \pm 0.14^{\mathrm{a}}$ & $+30.0 \pm 0.52^{\mathrm{b}}$ & $+30.9 \pm 0.52^{\mathrm{b}}$ & $+20.3 \pm 0.14^{\mathrm{a}}$ & $+21.7 \pm 0.14^{\mathrm{a}}$ \\
\hline
\end{tabular}

Description: P1 (Whole fish with bromelain), P2 (Whole fish with papain), P3 (Flesh with bromelain), P4 (Flesh with papain), P5 (Waste with bromelain), P6 (Waste with papain). Different superscripts in the same column show that there are significantly differences $(\mathrm{p}<0.05)$.

The portion of meat contains a lot of unsaturated fatty acids, namely oleic acid which caused the weight of the oil to increase due to the high molecular weight of the fatty acids. In contrast, the waste portion contains a lot of saturated fatty acid, palmitic, which has a higher molecular weight than oleic acid. The yield of milkfish oil in this study is close to research by Aditia et al. (2014) which utilized dry rendering method (pressing) with yield of crude milkfish oil as much as $2.1 \%$. Crude milkfish oil produced in this study ranged from $2-12 \%$. Therefore, this study's yield of pure milkfish oil is also close to the research by Aziza et al. (2015) which utilized rendering method with hexane solvent which produces pure milkfish oil yield of $2.365 \%$. The pure milkfish oil made in this study ranged from 0.72 to $1.28 \%$.

The density of pure fish oil ranges from $0.902-$ $0.944 \mathrm{~g} / \mathrm{mL}$. Whole fish oil treated with bromelain had the lowest density, while whole fish oil with papain had the highest density. Fish oil from flesh treated with bromelain enzyme had a density of $0.903 \mathrm{~g} / \mathrm{mL}$ and core with papain $0.920 \mathrm{~g} / \mathrm{mL}$. Meanwhile, fish oil from waste treated with bromelain at a rate of $0.912 \mathrm{~g} / \mathrm{mL}$ and papain of $0.917 \mathrm{~g} / \mathrm{mL}$. The specific gravity of the oil is also influenced by the molecular weight of the fatty enzyme at +3.1 and the lowest was the treatment of flesh with bromelain enzyme at +1.03 . The treatment with the highest $b^{*}$ value was flesh treated with papain at +30.9 , and the lowest was waste with bromelain at +20.3 . The effectiveness of different blanching processes can cause the difference in color test results on the oil sample and the damage that occurs to the oil. The more effective the blanching process is, the higher the brightness of the fish oil. If there are lots of free fatty acids or impurities found in fish oil due to the hydrolysis and neutralization processes, it will become cloudy (Sari et al., 2015).

The treatment with the highest absorbance value was flesh treatment with bromelain enzyme of $0.241 \mathrm{~A}$, while the lowest was whole fish with bromelain enzyme at $0.067 \mathrm{~A}$. The clarity level of flesh treatment ranged from $0.197-0.241 \mathrm{~A}$, waste $0.131-0.155 \mathrm{~A}$, and whole 0.067-0.091 A. The analysis results indicated that the treatment of differences in fish body parts had a significant effect $(\mathrm{p}<0.05)$ on the overall physical properties. While the different types of enzymes only had a significant effect $(\mathrm{p}<0.05)$ on density.

\subsection{The Effect of Treatment on Chemical Properties}


Table 2. Chemical properties of pure fish oil from Milkfish Silage (Chanos chanos) from Kamal market, Bangkalan

\begin{tabular}{lcccccc}
\hline \multirow{2}{*}{ Parameter } & \multicolumn{6}{c}{ Treatment } \\
\cline { 2 - 7 } & P1 & P2 & P3 & P4 & P5 & P6 \\
\hline FFA (\%) & $1.03 \pm 0.70^{\text {bc }}$ & $1.21 \pm 0.09^{\mathrm{c}}$ & $0.56 \pm 0.13^{\mathrm{a}}$ & $0.77 \pm 0.70^{\mathrm{bc}}$ & $0.95 \pm 0.70^{\mathrm{bc}}$ & $1.05 \pm 0.70^{\mathrm{bc}}$ \\
$\begin{array}{l}\text { Peroxide } \\
\text { (meq } / \mathrm{kg})\end{array}$ & $9.68 \pm 0.85^{\mathrm{b}}$ & $10.87 \pm 0.85^{\mathrm{b}}$ & $7.64 \pm 0.38^{\mathrm{a}}$ & $8.21 \pm 0.38^{\mathrm{a}}$ & $14.89 \pm 0.48^{\mathrm{c}}$ & $15.35 \pm 0.48^{\mathrm{c}}$ \\
\hline
\end{tabular}

Description: P1 (Whole fish with bromelain), P2 (Whole fish with papain), P3 (Flesh with bromelain), P4 (Flesh with papain), P5 (Waste with bromelain), P6 (Waste with papain). Different superscripts in the same column show that there are significantly differences $(\mathrm{p}<0.05)$.

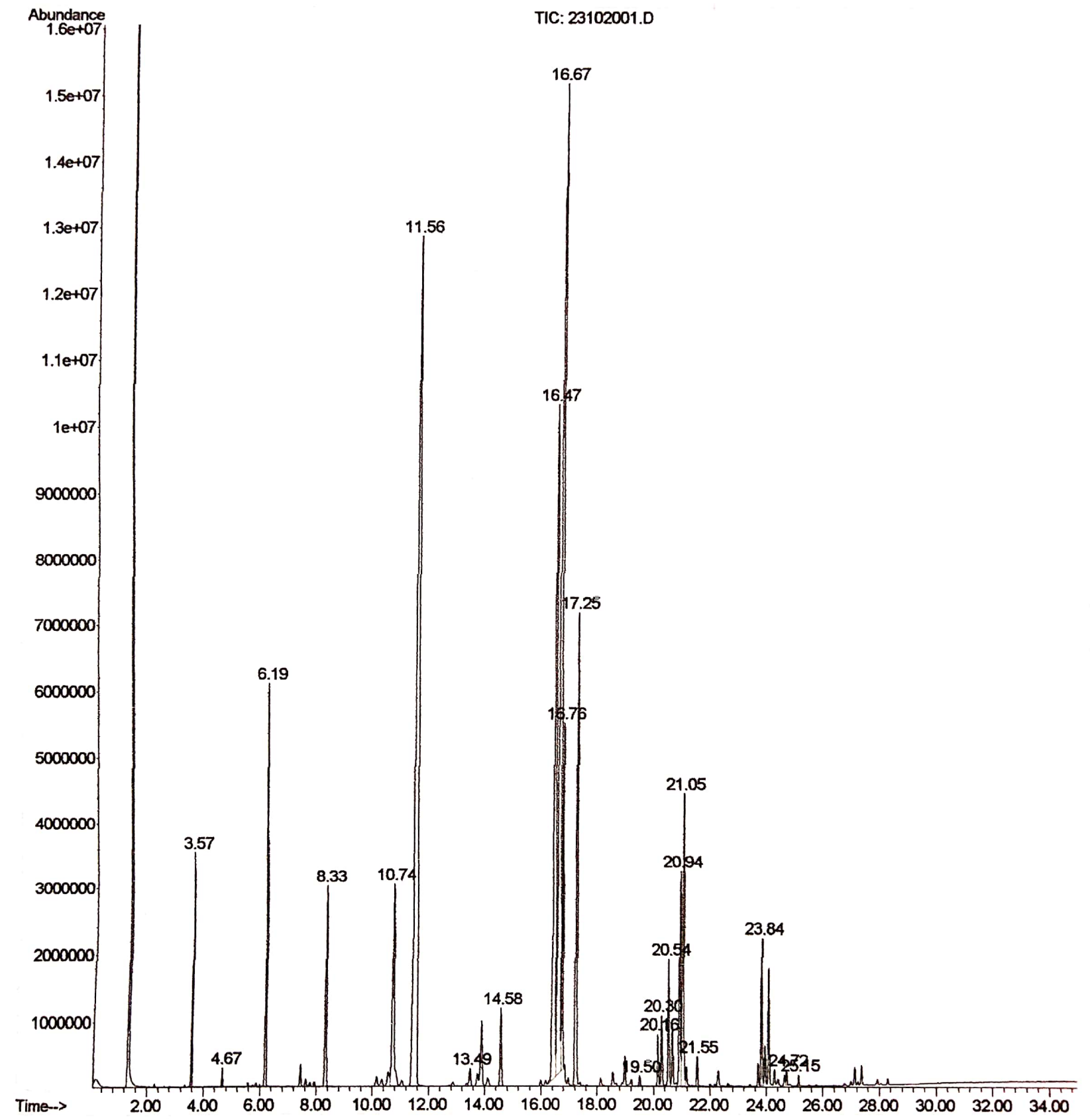

Figure 1. The chromatogram of the best treatment (flesh with bromelain) 
Table 3. Fatty acids profile of pure fish oil from Milkfish Silage (Chanos chanos) from Kamal market, Bangkalan

\begin{tabular}{|c|c|c|}
\hline Retention Time (RT) & Component Name & $\%$ Concentration \\
\hline 3.57 & Lauric Acid & 1.56 \\
\hline 4.67 & Tridecanoic Acid & 0.15 \\
\hline 6.194 & Myristic Acid & 4.13 \\
\hline 8.33 & Pentadecanoic Acid & 2.72 \\
\hline 11.56 & Palmitic Acid & 25.36 \\
\hline 13.49 and 14.58 & Margaric Acid & 1.37 \\
\hline 17.25 & Stearic Acid & 6.97 \\
\hline 19.51 & Nonadecanoic Acid & 0.12 \\
\hline 25.15 & Behenic Acid & 0.12 \\
\hline \multirow[t]{2}{*}{21.55} & Arakat Acid & 0.36 \\
\hline & ESFA & 42.86 \\
\hline 24.72 & Erucic Acid & 0.18 \\
\hline 16.67 & Oleic Acid & 22.39 \\
\hline 16.76 & Elaidic Acid & 4.02 \\
\hline 10.73 & Palmitoleic Acid & 4.18 \\
\hline \multirow[t]{2}{*}{21.05} & 11-Eicosenoic Acid & 4.13 \\
\hline & IMUFA & 34.90 \\
\hline 16.47 & Linoleic Acid & 14.54 \\
\hline 20.16 & Arachidonic Acid & 0.64 \\
\hline 20.30 and 23.85 & 5,8,11,14,17-Eicosapentanoic Acid (EPA) & 2.63 \\
\hline 20.55 & 7,10,13-Eicosatrienoic Acid & 1.57 \\
\hline \multirow[t]{2}{*}{20.94} & 11,14-Eicosadienoic Acid & 2.85 \\
\hline & 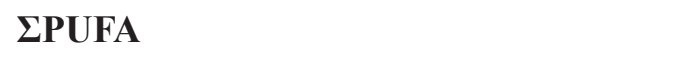 & 22.23 \\
\hline
\end{tabular}

to determine the oxidation process that occurs in the oil. High levels of FFA can reduce the quality of fish oil. FFA can be produced due to the hydrolysis of triglycerides which break the bonds of fatty acids and glycerol. Free fatty acids can also be caused by oxidation in the fatty acid double bonds (Putri et al., 2020). The whole fish with papain enzymes have the highest free fatty acid content $1.21 \%$, while the lowest was in the treatment of the flesh with bromelain enzymes of $0.56 \%$ (Table 2). The three types of treatment have different ranges of FFA content. The treatment with the lowest free fatty acid content was the flesh treatment. In this study, the FFA content of fish oil was lower than that of Aditia et al., 2014. This treatment resulted in an FFA of $2.61 \%$. The research results showed that the free fatty acid content was also lower than the commercial imported fish oil studied by Suseno et al. (2018), which was 0.88-3.62\%.
The free fatty acid content in this study has met IFOS and SNI $(<2 \%)$.

Peroxide compounds are formed as a result of the oxidation of free fatty acids contained in fish oil. The content of free fatty acids can be broken down into peroxide compounds resulting in rancidity. The test results obtained peroxide value in the range 8.21-15.35 $\mathrm{meq} / \mathrm{kg}$. The treatment that had the highest peroxide value was the waste treated with the papain enzyme at $15.35 \mathrm{meq} / \mathrm{kg}$. While the treatment with the lowest peroxide value was the flesh treated with bromelain enzyme of $7.64 \mathrm{meq} / \mathrm{kg}$. The three types of treatment had different peroxide value ranges where the lowest range is in the flesh treatment and the highest is in the waste treatment. These results also indicate that treatment with the bromelain enzyme produced peroxide values that were not significantly different from that of the papain 
enzyme. The average test results in this study was lower than the research by Aditia et al. (2014) which was $13.80 \mathrm{meq} / \mathrm{kg}$ and commercial imported oil of 2.55 $69.63 \mathrm{meq} / \mathrm{kg}$ of fat (Suseno et al., 2018). However, the research result oil still far exceeds the SNI standard $(<5$ $\mathrm{meq} / \mathrm{kg}$ ) of oil. High peroxide value can happen when the neutralization process occurs in high-temperature contact with the low yield of fish oil, which causes rapid oxidation.

The statistical analysis results showed a significant effect $(p<0.05)$ between the different treatments of body parts on free fatty acid contents and peroxide value in fish oil. The analysis results also showed a significant difference between whole and waste-free fatty acids content with flesh, which was indicated by different notations in the flesh treatment. This difference can be caused by the flesh fatty acid composition, which is mostly oleic acid. Oleic acid is an unsaturated fatty acid with a single, double bond (MUFA) which is more stable than the unsaturated fatty acid with multiple double bonds (PUFA). The characteristics of oleic acid that are not damaged by heating to a temperature of $200^{\circ} \mathrm{C}$ for 30 minutes (Putri et al., 2020) are thought to be the cause of flesh treatment having lower free fatty acid content and peroxide value. The statistical analysis results showed no significant effect ( $>0.05$ ) between the types of enzymes on free fatty acid content and peroxide value.

\subsection{Fatty Acids Profile}

The calculation of the concentration of fatty acid components was based on the peak retention time (Figure 1). The retention time that appeared was compared with the standard solution retention time so that the type of component detected in gas chromatography will appear. Then the types of fatty acid components are grouped according to the level of saturation (Table $3)$. The highest fatty acid content in flesh fish oil with bromelain enzyme is palmitic acid $(25.36 \%)$, oleic acid $(22.39 \%)$, and linoleic acid (14.54\%). The fish oil contained 20 detected fatty acid components, with ten types of saturated fatty acids (SFA), four types of mono unsaturated fatty acids (MUFA), and six types of poly unsaturated fatty acids (PUFA). The total of SFA in fish oil was $42.86 \%$ and the unsaturated fatty acids were $57.13 \%$. Fatty acid composition percentage (\%) of SFA in fish oil were $1.56,0.15,4.13,2.72,25.36,1.37$, $6.97,0.12,0.12$, and 0.36 respectively. Percentage (\%) of fatty acid composition of MUFA in fish oil were 0.18 , $22.39,4.02,4.18$, and 4.13, respectively. Percentage (\%) of fatty acid composition of PUFA in fish oil were $14.54,0.64,2.63,1.57$, and 2.85 , respectively. This indicates that the unsaturated fatty acid content is more dominant than the saturated fatty acid in fish oil. MUFA are found in flesh tissue so that treatment of the flesh with bromelain enzymes has a better quality fatty acid profile compared to waste. This is in line with the FFA analysis results, which showed that the free fatty acid content in the waste treatment was higher $(0.95-1.05 \%)$ compared to flesh treatment $(0.56-0.77 \%)$. The high content of free fatty acids indicates that saturated fatty acids are dominant so that they are easily hydrolyzed into free fatty acid and peroxide compounds. Fish oil also contains essential omega fatty acids, including oleic acid, arachidonic acid, EPA, eicosatrienoic acid, eicosadienoic acid, and eicosenoic acid.

\section{Conclusion}

Treatment with different types of enzymes (bromelain and papain) had no significant effect on pure milkfish oil quality, but the bromelain enzyme fish oil has higher purity. Treatment on different fish body parts (whole, flesh, and waste) had a significant effect on the quality of pure milkfish oil in terms of the parameters of specific gravity, color, clarity, free fatty acid content, and peroxide number. The best treatment was flesh bromelain enzymes with a yield of $1.25 \%$, density 0.903 $\mathrm{g} / \mathrm{mL}$, FFA content of $0.56 \%$, peroxide value of 7.64 $\mathrm{meq} / \mathrm{kg}$.

\section{Acknowledgment}

Writers would like to appreciate Department Agroindustrial Technology, Universitas Trunojoyo Madura, and Testing Service Unit Faculty of Pharmacy, Universitas Airlangga, for their support of all research activities and facilities.

\section{Authors' Contributions}

All authors have contributed to the final manuscript. Each author's contribution as follow, $\mathrm{Su}$; devised the main conceptual ideas and critical revision of the article. Ypa; collected data, drafted the manuscript, and designed the figures. All authors discussed the results and contributed to the final manuscript.

\section{Conflict of Interest}

The authors declare that they have no competing interests.

\section{Funding Information}

Research funding comes from the researchers themselves. 
JIPK. Volume 13 No 2. November 2021 / The Effect of Using Bromelain and Papain Enzymes on the Quality of ...

\section{References}

Aditia, R. P., Darmanto, Y. S., \& Romadhon. (2014). Perbandingan mutu minyak ikan kasar yang diekstrak dari berbagai jenis ikan yang berbeda. Jurnal Pengolahan Dan Bioteknologi Hasil Perikanan, 3(3):55-60.

Akhade, A., Koli, J., Sadawarte, R., \& Akhade, R. (2016). Functional properties of fish protein concentrate extracted from ribbon fish, Lepturacanthus savala by different methods. International Journal of Processing and Post Harvest Technology, 7(2):274-283.

Al-Abri, A. S., Mahgoub, O., Kadim, I. T., Al-Marzooqi, W., Goddard, S. J., \& Al-Farsi, M. (2014). Processing and evaluation of nutritive value of fish silage for feeding omani sheep. Journal of Applied Animal Research, 42(4):406-413.

Helrich, K. (1990). Official methods of analysis of the Association of Official Analytical Chemists $\left(15^{\text {th }}\right.$ ed). Arlington, Virginia: Association of Official Analytical Chemists, Inc.

Apituley, D. A. N., Sormin, R. B. D., \& Nanlohy, E. E. E. M. (2020). Karakteristik dan profil asam lemak minyak ikan dari kepala dan tulang ikan tuna (Thunnus albacares). AGRITEKNO: Jurnal Teknologi Pertanian, 9(1):10-19.

Aziza, I. N., Maulana, I. T., \& Sadiyah, E. R. (2015). Perbandingan kandungan Omega 3 dalam minyak ikan bandeng (Chanos chanos) yang segar dengan ikan bandeng yang dikeringkan di pasar. SPeSIA Seminar Penelitian Sivitas Akademika Unisba, 1(2):539-544.

Dieffenbacher, A., \& Pocklington, W. D. (1992). Standard methods for the analysis of oils, fatsand derivatives (1st suppl. to the 7th ed.). Oxford: Blackwell Scientific Publications.

Feryana, I., Suseno, S., \& Nurjanah. (2014). Pemurnian minyak ikan makerel hasil samping penepungan dengan netralisasi alkali. Jurnal Pengolahan Dan Bioteknologi Hasil Perikanan, 17(3):207-214.

Gbogouri, G. A., Linder, M., Fanni, J., \& Parmentier, M. (2006). Analysis of lipids extracted from salmon (Salmo Salar) heads by commercial proteolytic enzymes. European Journal of Lipid Science and Technology, 108(9):766-775.

Hathwar, S. C., Bijinu, B., Rai, A. K., \& Narayan, B. (2011). Simultaneous recovery of lipids and proteins by enzymatic hydrolysis of fish industry waste using different commercial proteases. Applied Biochemistry and Biotechnology, 164(1):115-124.

Liu, H., Wang, L., Yang, T., Zhang, G., Huang, J., Sun, J., \& Huo, J. (2016). Optimization and evaluation of fish oil microcapsules. Particuology, 29:162168.

Lúcia, V., Maura, V., Bermúdez, S., Luis, A., Oliveira, L. De, Kleinberg, M. N., Tasso, R. De, Ribeiro, M., Ferreira, R., \& Abreu, A. De. (2015). Characterization of a hydrolyzed oil obtained from fish waste for nutraceutical application. Food Science and Technology, 35(2):321-325.

Makhoukhi, B., Didi, M. A., Villemin, D., \& Azzouz, A. (2009). Acid activation of bentonite for use as a vegetable oil bleaching agent. Grasas Y Aceites, 60(4):343-349.

Mbatia, B., Adlercreutz, D., Adlercreutz, P., Mahadhy, A., Mulaa, F., \& Mattiasson, B. (2010). Enzymatic oil extraction and positional analysis of $\omega-3$ fatty acids in nile perch and salmon heads. Process Biochemistry, 45(5):815-819.

Murthy, L. N., Padiyar, P. A., Rao, M., \& Asha, K. K. (2016). Nutritional profile and heavy metal content of cultured milkfish (Chanos chanos). Fishery Technology, 53:245-249.

Needham, S., \& Funge-Smith, S. (2015). The consumption of fish and fish products in the AsiaPacific region based on household surveys. Rome: Food and Agriculture Organization of The United.

Pandiangan, M., Kaban, J., Wirjosentono, B., \& Silalahi, J. (2019). Analisis kandungan asam lemak Omega 3 dan Omega 6 pada minyak ikan mas (Cyprinus Carpio). Talenta Conference Series: Science and Technology (ST), 2(1):37-44.

Pravinkumar, M., Eugien, L. X., Viswanathan, C., \& Raffi, S. M. (2015). Extraction of fish body oil from sardinella longiceps by employing direct steaming method and its quantitative and qualitative assessment. Journal of Coastal Life Medicine, 3(12):962-966.

Putri, D. N., Wibowo, Y. M. N., Santoso, E. N., \& Romadhania, P. (2020). Sifat fisikokimia dan profil asam lemak minyak ikan dari kepala kakap merah (Lutjanus malabaricus). AgriTECH, 40(1):31-38.

Ramakrishnan, V. V., Ghaly A. E., Brooks, M. S., \& Budge, S. M. (2013). Extraction of oil from mackerel fish processing waste using alcalase 
enzyme. Enzyme Engineering, 2(2):1-10.

Routray, W., Dave, D., Ramakrishnan, V., \& Murphy, W. (2018). Production of high quality fish oil by enzymatic protein hydrolysis from cultured atlantic salmon by-products: investigation on effect of various extraction parameters using central composite rotatable design. Waste and Biomass Valorization, 9(11):2003-2014.

Sari, R. N., Utomo, B. S. B., Basmal, J. \& Kusumawati, R. (2015). Pemurnian minyak ikan hasil samping (pre-cooking) industri pengalengan ikan lemuru (Sardinella lemuru). Jurnal Pengolahan Hasil Perikanan Indonesia, 18(3):276-286.

Sugata, M., Wiriadi, P. F., Lucy, J., \& Jan, T. T. (2019). Total lipid and Omega-3 content in pangasius catfish (Pangasius pangasius) and milkfish
(Chanos chanos) from Indonesia. Malaysian Journal of Nutriton, 25(1):163-169.

Suseno, S. H., Tajul, A. Y., \& Wan Nadiah, W. A. (2011). The use of passive filtration for optimization of magnesol xl function for improving the quality of Sardinella lemuru oil. International Research Journal of Biochemistry and Bioinformatics, 1(5):103-113.

Suseno, S. H., Jacob, A. M., Yocinta, H. P., \& Kamini. (2018). Kualitas minyak ikan komersial (softgel) impor di wilayah Jawa Tengah. Jurnal Pengolahan Hasil Perikanan Indonesia, 21(3):556-564.

Taati, M. M., Shabanpour, B., \& Ojagh, M. (2018). Investigation on fish oil extraction by enzyme extraction and wet reduction methods and quality analysis. AACL Bioflux, 11(1):83-90. 